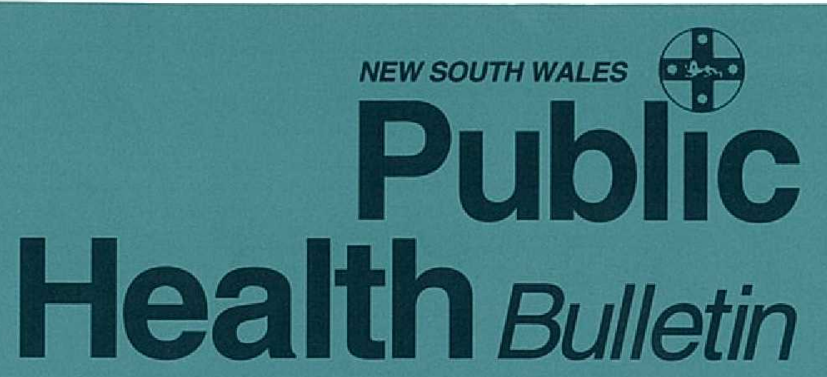

\section{STUDY OF PUBLIC SWIMMING POOLS AND SPA POOLS IN NSW, 1993}

Neil Shaw, Senior Environmental Health Officer,

Western Sector Public Health Unit

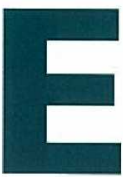

nvironmental Health Officers of NSW Public Health Units surveyed 1,291 public swimming and spa pools during the 1992-93 financial year. Each pool was tested for compliance with the NSW guidelines on disinfection. While high failure rates of pool disinfection were found in all categories, the survey also identified factors which will be targeted in a response strategy.

\section{INTRODUCTION}

There is a wide range of pathogenic bacteria, fungi, viruses and protozoa that may be transmitted through inadequately disinfected swimming pools and spa pools. These microorganisms may cause infection in ears, eyes, skin, mouths, noses, respiratory systems, intestinal and uro-genital tracts or central nervous systems ${ }^{1}$. A powerful and swift disinfection residual in the body of the pool water is necessary to prevent pathogen survival and transmission. Additionally, an oxidising agent is required to oxidise dissolved organic matter and reduce turbidity ${ }^{2}$.

The Public Health Regulation 1991 states that people responsible for public swimming pools and spa pools must ensure the pool water has been disinfected to prevent the spread of certain diseases. Under the Public Health Act 1991, the NSW Health Department issued guidelines for disinfecting public swimming pools and spa pools. The guidelines provide pool owners with information about bacteriological and chemical standards for adequate pool disinfection ${ }^{3}$.

During the 1992-93 financial year a Statewide survey of public swimming pools and spa pools was carried out to determine compliance with NSW Health Department guidelines for chemical parameters.

\section{METHOD}

The survey was conducted over 12 months between July 1, 1992 and June 30, 1993. This period allowed for inspection of pools which were operated either seasonally or continuously.

Environmental Health Officers (EHOs) of all 14 Public Health Units (PHUs) in NSW conducted the inspections and tests. Each PHU compiled a list of known public swimming pools and spa pools. A systematic random sample of pools in NSW stratified by PHU was used to select pools for inclusion in the study. A total of 1,291 pools was tested during the survey.

All PHUs were supplied with a new temperature meter and Palintest Photometer 5000 equipped to carry out the appropriate chemical tests of chemical parameters including free residual chlorine/bromine, total residual chlorine/bromine, combined residual chlorine, $\mathrm{pH}$, reserve (total) alkalinity and cyanurate. Table 1 summarises the significance of each of these chemical parameters.

\section{Contents}

\section{Articles}

131 Study of public swimming pools and spa pools in NSW, 1993

134 The NSW refugee screening program

\section{Infectious Diseases}

136 Measles epidemic, South Coast NSW

\section{Hydatid disease}

\section{8-140 Tables}

\section{Correspondence}

Please address all correspondence and potential contributions to:

\section{The Editor}

NSW Public Health Bulletin, Public Health Division, NSW Health Department

Locked Bag No 961 , North Sydney NSW 2059 Telephone: (02) 3919218 Facsimile: (02) 3919232 


\begin{tabular}{|c|c|}
\hline \multicolumn{2}{|c|}{$\begin{array}{l}\text { CHEMICAL PARAMETERS MEASURED } \\
\text { IN THE SURVEY OF POOLS }\end{array}$} \\
\hline Parameter & Significance \\
\hline Free chlorine/bromine & $\begin{array}{l}\text { The active free form of the } \\
\text { disinfectant and is proportional } \\
\text { to disinfecting power. It is not } \\
\text { combined with other molecules. } \\
\text { Minimum levels are required. }\end{array}$ \\
\hline Total chlorine/bromine & $\begin{array}{l}\text { A measure of the total quantity } \\
\text { of disinfectant in its various } \\
\text { forms. Free chlorine }+ \text { combined } \\
\text { chlorine }=\text { total chlorine. } \\
\text { Maximum levels are specified. }\end{array}$ \\
\hline Combined chlorine & $\begin{array}{l}\text { A measure of chlorine or } \\
\text { bromine combined with organic } \\
\text { or nitrogenous molecules. These } \\
\text { compounds generally have a } \\
\text { much lower disinfecting power } \\
\text { and can be severe irritants of } \\
\text { mucous membranes. Maximum } \\
\text { levels are specified. }\end{array}$ \\
\hline $\mathrm{pH}$ & $\begin{array}{l}\text { The higher the } \mathrm{pH} \text { the less } \\
\text { disinfectant is available in the } \\
\text { free form (i.e. less disinfection } \\
\text { power) but the greater the } \\
\text { bather comfort. Ideal is } 7.5 \text {. } \\
\text { A range is specified. }\end{array}$ \\
\hline Reserve alkalinity & $\begin{array}{l}\text { A measure of the pool buffer } \\
\text { capacity to prevent rapid swings } \\
\text { in } \mathrm{pH} \text {. A minimum is specified. }\end{array}$ \\
\hline Cyanurate & $\begin{array}{l}\text { Also known as stabiliser, it } \\
\text { reduces the loss of chlorine from } \\
\text { a pool due to UV light catalysed } \\
\text { reactions. A range is specified. }\end{array}$ \\
\hline
\end{tabular}

\section{Swimming pools and spa pools}

\section{$\checkmark$ Continued from page 131}

Tests followed the methods specified in the manual supplied with the photometer. All Senior EHOs received training on the use of the photometer and survey methods. Only one EHO from each PHU was asked to perform the inspections to ensure consistent inspection methods. A data checksheet was developed for ease of data collection and entry. Information was collected on pool classification, location (indoor or outdoor), water temperature, type of dosing, use of stabiliser, log book status and perceived inspection frequency. Completed checksheets were sent to the Western Sector PHU for data entry.

As the sampling fraction was not uniform in all PHUs, data were weighted by the inverse of the sampling fraction to provide adjusted point estimates for NSW as a whole. Tests of significance for proportions were assessed using the Chi-square test for independence. P-values are presented without adjustment for multiple comparisons. Although the sample size is large with a very high sampling fraction, a p-value of less than 0.01 is considered significant.

\section{RESULTS}

Failure rates for various parameters are contained in

Table 2. The overall failure rate was 65 per cent. Free

\section{TABLE 2}

FAILURE RATES OF CHEMICAL PARAMETERS OF ALL POOLS $(1,291$ POOLS $)$

\begin{tabular}{lc|}
\hline Parameter & Significance \\
\hline Free chlorine/bromine & 44 \\
Total chlorine/bromine & 33 \\
Combined chlorine & 10 \\
pH & 23 \\
Reserve alkalinity & 22 \\
Cyanurate & 9 \\
Overall & 65
\end{tabular}

- $=$ failure due to one or more of the above parameters.

\begin{tabular}{|lcc|}
\hline \multicolumn{2}{l|}{ TABLE 3 } & \multicolumn{2}{l|}{} \\
\hline \multicolumn{1}{l}{ FAILURE RATE OF EACH CATEGORY } \\
\hline Pool category & No. inspected & $\%$ failed \\
\hline Municipal pools - all & 443 & 57 \\
- outdoor & 401 & 55 \\
- indoor & 42 & 74 \\
Business pools - all & 676 & 67 \\
- outdoor & 524 & 68 \\
- indoor & 152 & 66 \\
Business spas - all & 170 & 79 \\
- outdoor & 53 & 81 \\
- indoor & 117 & 78 \\
\hline
\end{tabular}

- = major pool category

chlorine/bromine, which is a measure of the disinfection power in the pool and is proportional to the killing rate of pathogenic organisms ${ }^{2}$, was the parameter with the highest failure rate.

Pool category results are contained in Table 3 . For data analysis purposes municipal pools included municipal spa pools, because there were only nine, while business pools do not include spa pools. Business spa pools had the highest failure rate while municipal pools had the lowest failure rate.

The overall failure rate for all outdoor pools was 63 per cent, and for all indoor pools 71 per cent. No significant difference was found between total indoor and total outdoor pools $\left(x_{1}^{2}=6.30, p>0.01\right)$. Significant differences were found between outdoor $\left(x_{2}^{2}=23.70, \mathrm{p}<0.01\right)$ but not indoor pool categories $\left(x_{2}^{2}=4.79, \mathrm{p}>0.01\right)$.

About 74 per cent of pools were continuously dosed. Based on disinfectant levels alone, continuously dosed pools revealed a failure rate of 37 per cent and hand-dosed pools had a failure rate of 58 per cent $\left(x_{1}^{2}=47.48, p<0.01\right)$.

Outdoor stabilised pools, containing cyanurate, had a higher free chlorine failure rate of 52 per cent than outdoor unstabilised pools which had a 43 per cent failure rate $\left(x_{1}^{2}=11.26, \mathrm{p}<0.01\right)$.

Log books were reported at about half the pools. Where log books were kept a lower free chlorine/bromine failure rate 
of 34 per cent was found compared with 54 per cent failure rate where a log book was not kept $\left(x_{1}^{2}=43.10, p<0.01\right)$.

The failure rate in premises which were "regularly inspected" by an authority was 28 per cent, compared with 39 per cent in premises "infrequently inspected" and 53 per cent in premises "not inspected" $\left(x_{2}^{2}=55.26, \mathrm{p}<0.01\right)$.

\section{DISCUSSION}

The three main categories of public pools and spas were chosen to reflect the perceived level of understanding of pool operation by pool supervisors. Municipal pool supervisors receive training through a technical college course supplemented by a form of apprenticeship. Municipal pools therefore should have the lowest failure rate. Business pool and spa supervisors have little formal training, if any, in pool operation and chemistry.

The general trend was that lower failure rates were found in municipal pools. Other pool categories were far worse. The highest failure rates were due to a lack of disinfection agent. Lower failure rates were found when the following operational procedures were followed:

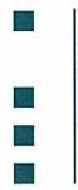

pools used continuous disinfection rather than hand (slug) dosing;

stabilising compounds were not used;

$\log$ books were maintained; and

regular inspections were carried out by an authority.

The high failure rates suggest the present approach based on self-regulation may need to be supplemented with other strategies such as the development of uniform education programs for presentation to non-municipal pool operators. There may also be a case for considering greater legislative control over pool disinfection.

The survey highlights the need for a corrective strategy to be developed. In particular, close attention should be paid to: educating pool operators, preferably at a local level; insisting on continuously and preferably automatically controlled dosing;
- insisting that $\log$ books be maintained by pool operators; and

- where staff resources allow, introduction of regular inspections.

\section{FOLLOW-UP ACTION}

A training package has been developed and presented to PHU EHOs. Many PHUs have presented the training package to local authorities and some have run training seminars for public pool operators. Simultaneously, the departmental pool guidelines are being reviewed to dovetail with suggested amendments to the Public Health Regulation, 1991.

Copies of the detailed report are available from the author, Western Sector Public Health Unit, 13 New St, North Parramatta, NSW, 2151, (02) 840 3795, fax (02) 8403817.

\section{ACKNOWLEDGMENTS}

The data collection and inspections for this study were completed with the co-operation of all 14 NSW Health Department PHUs. The support of the PHU Directors, Senior Environmental Health Officers and Environmental Health Officers is gratefully acknowledged.

The contributions of the following staff from the Western Sector PHU are greatly appreciated: Tien Chey (biostatistician) and Wayne Smith (epidemiologist) for statistical guidance and support; Marea Mears (data entry operator) for accurate data entry; and Bin Jalaludin (Deputy Medical Officer of Health) and Louisa Jorm (epidemiologist) for reviewing the draft paper and making constructive suggestions.

1. Galbraith NS. Infections associated with swimming pools. In: The Australian Health Surveyor, August/September 1980, Australian Institute of Health Surveyors, Sydney.

2. White GC. The Handbook of Chlorination. 3rd ed, New York: Van Nostrand Reinhold, 1992.

3. NSW Health Department 1991. Guidelines for disinfecting public swimming pools and spa pools.

\section{PUBLIC HEALTH EDITORIAL STAFF}

The editor of the Public Health Bulletin is Dr Michael Frommer, Director, Research and Development, NSW Health Department; production manager is Dr Marie-Louise Stokes, and assistant editor is Dr Valerie Delpech.

The Bulletin aims to provide its readers with population health data and information to motivate effective public health action. Articles, news and comments should be 1,000 words or less in length and include a summary of the key points to be made in the first paragraph.

Please submit items in hard copy and on diskette, preferably using WordPerfect 5.1, to the editor, NSW Public Health Bulletin, Locked Mail Bag 961, North Sydney 2059. Facsimile (02) 3919232.

Please contact your local Public Health Unit to obtain copies of the NSW Public Health Bulletin. 